\title{
Influencing Elite Opinion on Gender Equality through Framing: A Survey Experiment of Elite Support for Corporate Board Gender Quotas
}

\author{
Article published in Politics \& Gender DOI: https://doi.org/10.1017/S1743923X19000060
}

\author{
Mari Teigen \\ mari.teigen@socialresearch.no \\ Institute for Social Research, Oslo \\ Rune Karlsen \\ rune.karlsen@media.uio.no \\ University of Oslo \\ and \\ Institute for Social Research, Oslo
}

\begin{abstract}
This article contributes to both the scholarly debates on the controversies over gender quotas and the body of knowledge on framing effects through an investigation of whether national elites, individuals in top positions across ten sectors of Norwegian society, are susceptible to positive framing of corporate board gender quotas (CBQs). Elites are thought to be more resistant to framing, and their predispositions are found to be stronger and more consistent than those of the general public. However, few if any studies have empirically investigated framing effects on national elites. We report on an experiment embedded in a comprehensive survey of Norwegian national elites. The results clearly indicate that elites are susceptible to framing. When exposed to frames highlighting both male dominance among the business elite and the success of CBQs in achieving gender balance on corporate boards, elites were significantly more likely to support gender quotas. Framing effects were primarily found among men, not women, and contrary to expectation, effects were stronger among the business elite. These results should direct our attention to how the framing of issues also influences key stakeholders, and that policymakers should consider opposition to gender equality measures as something that has the propensity to change.
\end{abstract}

Keywords: Elites; gender quotas; corporate board gender quotas; business elites; framing; experiment 


\section{Introduction}

In the past decade, legislation introducing corporate board gender quotas (CBQs) has spread throughout Europe. ${ }^{1} \mathrm{CBQ}$ s have been contested on several grounds, and opposition has been particularly salient among the business elite, emphasizing autonomy of the business owners to freely choose board members and opposition to state intervention (see Skjeie and Teigen 2003; Tienari et al. 2009; Teigen 2015; Chandler 2016; Lépinard and Marin 2018). Opinions about gender quota regulations are strongly interrelated to larger ideologically fronts concerning individual rights, equal treatment, fairness, and justice; and therefore, arguably, considered fixed and unmovable. But how strong are opinions opposing corporate quotas? Is it possible to change even elite opinions on these matters? If so, the implications for future policy development and implementation in the gender-equality policy field could be profound.

Studies across social science fields have shown that selecting, highlighting, or emphasizing certain aspects of an issue, often referred to as framing, influences peoples' opinions (e.g., Chong and Druckman 2007a; Scheufele and Iyengar 2017). However, the perspective in most of these studies is that elites, in tandem with the media, influence public opinion by deciding on the frame of issues or events (see, e.g., Chong and Druckman 2007b; Zaller 1992; Leeper and Slothuus 2015). The extent to which elites are also susceptible to the framing of issues is more of a moot point. The general consensus seems to be that elites are more resistant, as their predispositions are stronger and more consistent than those of the general public (e.g., Zaller 1992). These studies typically rely on population-based surveys; few if any studies have empirically investigated framing effects on national elites.

In this paper, we study the extent to which a positive framing of CBQs - or "corporate quotas" - influences elite opinions on the topic. We utilize a survey experiment embedded in a unique, comprehensive survey of top Norwegian elites: the 2015 Norwegian Leadership 
Study. The sample consists of 1351 individuals occupying top positions across 10 sectors of Norwegian society. We study the effect of frames emphasizing information about the prevailing male dominance among the business elite, combined with information about the success of CBQs in promoting gender balance on corporate boards. We study the effect of framing on two types of dependent variables. The first is support for CBQs. In addition, in debates on CBQs a main claim has been that such policy would also have wider so called "ripple" effects, increasing gender balance in the business elite in general. We therefore also investigate whether positive CBQs framing influences the extent to which CBQs are considered necessary to promote gender balance in business life in general.

The results indicate that elites are indeed susceptible to framed information about gender quotas. Moreover, and contrary to expectations, effects are generally stronger in the business elite than in other elite groups. Effects are first and foremost found in relation to general CBQs support. There are more modest effects on opinions regarding CBQs being necessary to promote gender balance in business life. The results indicate that elite opinions are not as strong and consistent as one might expect, given earlier research on predispositions as well as public debates on CBQs. Many in the top national elite are susceptible to changing their opinions based on information highlighting the positive effects of quota schemes on the gender composition of corporate boards. In conclusion, we argue that this expands the space for maneuvering for policymakers working on the formulation and implementation of genderequality measures. Moreover, knowledge about possibilities to increase support for gender equality measures, in countries where CBQs are in effect, is essential as it can prevent backlash. The paper thus contributes to both the scholarly debates on gender quotas and the body of knowledge on framing effects. 


\section{Gender quotas}

Gender quotas are often regarded as a controversial means of regulating the gender composition of decision-making positions (Hughes et al. 2017; Piscopo and Muntean 2018). Such measures have been most widespread in political structures. Within the last couple of decades, electoral quotas have diffused worldwide and currently half of the countries of the world use some kind of electoral quotas for their parliaments. ${ }^{2}$ Quotas in politics are widely considered a "fast track" to gender balance (Dahlerup and Freidenvall 2005; Dahlerup 2008; Krook 2009). ${ }^{3}$ However, gender quotas have not only spread across countries; they have also spread from the political to the economic field. CBQs extend the scope of gender-equality policies by even targeting privately owned businesses, and corporate quotas are generally considered even more contested than political quotas (cf. Chandler 2016; Piscopo and Muntean 2018). This relates to the institutional context, where legislatures are expected to reflect the people, and descriptive representations of gender therefore signal representativeness, while corporations have consumers who primarily cares about the goods purchased and less with how the corporate board is composed (Piscopo and Muntean 2018; Teigen 2018b). Still an emerging concern with corporate social responsibility connects gender balance to company interests, either narrowly understood as the effect of gender balance to increase profit and reduce loss, or understood within a wider frame of gender balance as an aspect of corporate social responsibility (Terjesen and Sealy 2016).

Although corporate quotas move beyond the right based language of political participation generating strong controversies over these measures, corporate and political quotas are typically opposed by a notably similar set of standard arguments. Political quotas are argued to violate equality and for being un-meritocratic, undemocratic, and demeaning to women (Hughes et al. 2017). Similarly, corporate quotas are often considered to violate 
equality, being un-meritocratic, at stake with shareholder democracy, and demeaning to women (Tienari et al. 2009; Teigen 2012a; Seierstad et al. 2017).

The opposition against corporate quotas has been particularly strong among business leaders in all countries where CBQs have been debated (Tienari et al. 2009; Menéndez and González 2012; Teigen 2015; Chandler 2016; Axelsdóttir and Einarsdóttir 2016; Lépinard 2018). In most countries, representatives from the business sector have participated in the debate as the most outspoken opponents of CBQs. In what follows, we discuss whether elite support for CBQs might nevertheless be swayed by how the issue is framed.

\section{Frames and framing effects}

In public debate and the news media, a political problem, an issue, or an event is never covered from all angles. Some aspects are always selected and highlighted, and this is referred to as frames and framing (Verloo 2005; Chong and Druckman 2007a; Entman 1993; Scheufele and Iyengar 2017). Frames typically select and highlight some aspects of an event, define the problem, argue for causes, make judgments, and/or suggest remedies (Entman 1993, 52). In gender studies, frames and the importance of how political problems are represented have been a central area of research in recent years (e.g., Bacchi 2009; Verloo 2005; Lombardo et al. 2009). For example, gender quotas could be framed as discrimination or anti-discrimination; discrimination or the special contribution of women in maledominated fields; "helping" women or measures against the overrepresentation of men. These are examples of struggles over where to place "the burden of proof", those defending status quo or those advocating equality (Teigen 2000; Bacchi 2009; Murray 2014). In public debate, although one frame might be dominant, there might be several "competing" frames, as different actors try to dominate public debate with their particular frame (Disch 2011; Chong and Druckman 2013). 
Based on the above description of the debates on the introduction of CBQs, the dominant frames in most countries have arguably been male dominance among the business elite vs. the autonomy of business owners to freely choose their board members. In what follows, we discuss how such frames are likely to influence peoples' opinions.

\section{Attitude and opinion change - framing effects}

The specific framing of and issue or event also affect peoples' opinions on the issue (see, e.g., Iyengar 1991; Zaller 1992; Scheufele and Iyengar 2017 for an overview). Frames define the packaging of a problem, an issue, or event in such a way as to encourage certain interpretations and to discourage others. This perspective is rooted in the so-called conventional expectancy model developed within research on attitudes and attitude change (e.g., Ajzen and Fishbein 1980). In this influential model, an attitude toward an object is thought of as the weighted sum of a series of beliefs (or considerations) about the object (see, e.g. Chong and Druckman 2007a for a discussion related to framing). ${ }^{4}$ Take attitudes towards gender quotas as an example; here, an attitude can be the result of considerations related to the level of gender equality in society, in general, and in the business sector, in particular, but also include considerations related to rights connected to ownership, state intervention, etc.

The idea behind framing effects is that when the presentations of an issue emphasize one aspect of that issue or event, the corresponding consideration by the audience will become more salient or given more weight than other considerations. ${ }^{5}$ Such framing effects on attitudes are supported by numerous studies from several disciplines and fields. The study of Tversky and Kahneman (1981) showed the manner in which peoples' choices are influenced by the framing of a problem, even when the information presentation is identical. This is referred to as "equivalency frames." "Emphasis frames" offer "qualitatively different yet potentially relevant considerations" that individuals use to make judgments (Chong and Druckman 2007a, 114). A much-used example is that people are much more inclined to 
accept a Ku Klux Klan rally when the news report is framed in terms of free speech than when it is framed in terms of public safety concerns. Such framing effects are found in numerous studies, for instance in regards to framing deservingness to win support for welfare state retrenchment (Slothus 2009), and more recently if different welfare reform pressure frames makes people more worried about the welfare state (Goerres, Karlsen and Kumlin 2018).

At the outset, therefore, we expect that people are influenced by how CBQs are framed and that referring to the success of CBQs in achieving gender balance in the maledominated business sector will make elites more positive toward the scheme. But are elites a special breed that is next to impossible to influence? Theories and models of framing and attitude change are mostly about changes in the opinion of the general public. Indeed, as mentioned earlier, most of the extensive literature on framing explicitly treats the phenomenon as elite frames influencing public opinion. Few, if any of these studies investigate whether elites themselves are susceptible to framing. Most studies of opinion and opinion change distinguish between people based on education, income, and/or political awareness. The general consensus from these studies seems to be that it is difficult to influence elites — meaning the highly educated, high income, and political aware — as they have stronger and more consistent predispositions (Zaller 1992). Strong predispositions reduce framing effects, as they increase resistance to disconfirming information (Chong and Druckman 2007, 111). Ever since Converse's (1964) seminal study, social elites have been found to have stronger, more coherent, and stable attitudes. Still, even people with strong predispositions are susceptible to framing, particularly in relation to new issues, and recent work suggest that framing at least influences the attention of the political elite (Walgrave et al. 2018). As for knowledge about the issue, the evidence is mixed. Some studies point to it 
being more difficult to influence people with a high level of knowledge, while other studies report the contrary (see Chong and Druckman 2007 for an overview).

On the basis of existing research, although elites are considered to have stronger predispositions than the general public, the evidence suggests that a positive CBQs frame will increase support for CBQs (Hypothesis 1a) and increase adherence to the opinion that CBQs are necessary to achieve gender equality among the business elite (Hypothesis 1b).

As elites are found to have stronger predispositions, we expect the effects of framing to be rather small. Following the same logic, we are also able to formulate expectations related to gender and elite groups: It should be more difficult to influence elites with particular interest or knowledge about CBQs, as they most likely have stronger and more consistent predispositions on the issue. Nevertheless, it is difficult to hypothesize gender differences in a unidirectional manner. On the one hand, gender quotas are closer to home for women than men, and thus, they might be more influenced then men when they hear about male dominance and the success of CBQs. We would therefore expect that framing effects will be stronger for women than for men (Hypothesis 2). On the other hand, gender equality issues and gender quotas are most likely more salient for elite women than for elite men. Many, if not most, men have probably spent less time thinking about gender issues than women. Consequently, they may have weaker predispositions and more susceptible to information and framing. Indeed, Clayton, O’Brien and Piscopo's (2018) work on "all-male panels" suggests that information about women's presence on decision-making bodies send stronger signals to men than to women when it comes to considering decisions legitimate. Thus, for gender, we also formulate the opposite expectation: framing effects will be stronger for men than for women (Hypothesis 3).

The differing effects between elite-group expectations are more easily hypothesized based on proximity and knowledge. CBQs affect business elites to a greater extent than other 
elite groups, as the jurisdiction is directly related to their sector. Moreover, as they live and breathe in the sector, the treatment should be more salient for this elite group than for other groups. We therefore expect that the business elite will be more resistant to information about male dominance and the success of gender quotas than other elite groups (Hypothesis 4).

\section{The Norwegian context: debate on corporate boards}

In 2003, as the first country in the world, the Norwegian parliament adopted a regulation demanding the representation of at least 40 percent of each gender on the boards of stateowned, inter-municipal, and public limited companies (PLCs). ${ }^{6}$ Thereon similar regulations have been adopted in a range of countries including Spain, Iceland, France, Belgium, Germany, Portugal and Austria (Fagan et al. 2012; Teigen 2012b; Terjesen et al. 2015; Seierstad et al. 2017; Piscopo and Muntean 2018; Lépinard and Marin 2018).

The corporate board gender quotas regulation was set out in the Norwegian Public Limited Liability Companies Act in Articles 6-11a for PLCs, with parallel formulations in other parts of company legislation regarding state-owned companies etc.. The rules regarding the representation of both sexes are to be applied separately to employee-elected and shareholder-elected representatives in order to ensure independent election processes. ${ }^{7}$ The CBQs were expanded to include cooperative companies in 2008 and municipal companies in 2009. The boards of the numerous but often small- and medium-sized LTDs ${ }^{8}$ are not subject to such regulations. ${ }^{9}$

For state-owned companies and inter-municipal companies, the regulation adopted in 2003, was effectuated in 2004. For PLCs the adopted regulation in 2003, was formulated as "threat" legislation: Had PLCs not voluntarily met the requirement for gender composition by July 2005, the regulation would be effectuated. Although female representation increased 
between 2003 and 2005, the target of 40 percent of women was not reached for the boards of the PLCs. Thus, in December 2005, the government decided to effectuate a CBQs regulation for the boards of start-up PLCs from 2006 and for all PLCs from 2008. The 40 percent target was met, as the regulation was fully implemented in 2008 . The rather tough sanctions attached to the legislation probably contributed to the successful implementation. The Companies Act applies identical sanctions for breach of all its rules, with forced dissolution being the final step for companies violating the regulations of this Act. The Norwegian register of business enterprises established to ensure compliance with the law reports on companies to ensure compliance.

Figure 1. Proportion of Women on the Boards of Public Limited Companies (PLC) and Limited Companies (LTD), Norway, 2002-2017.

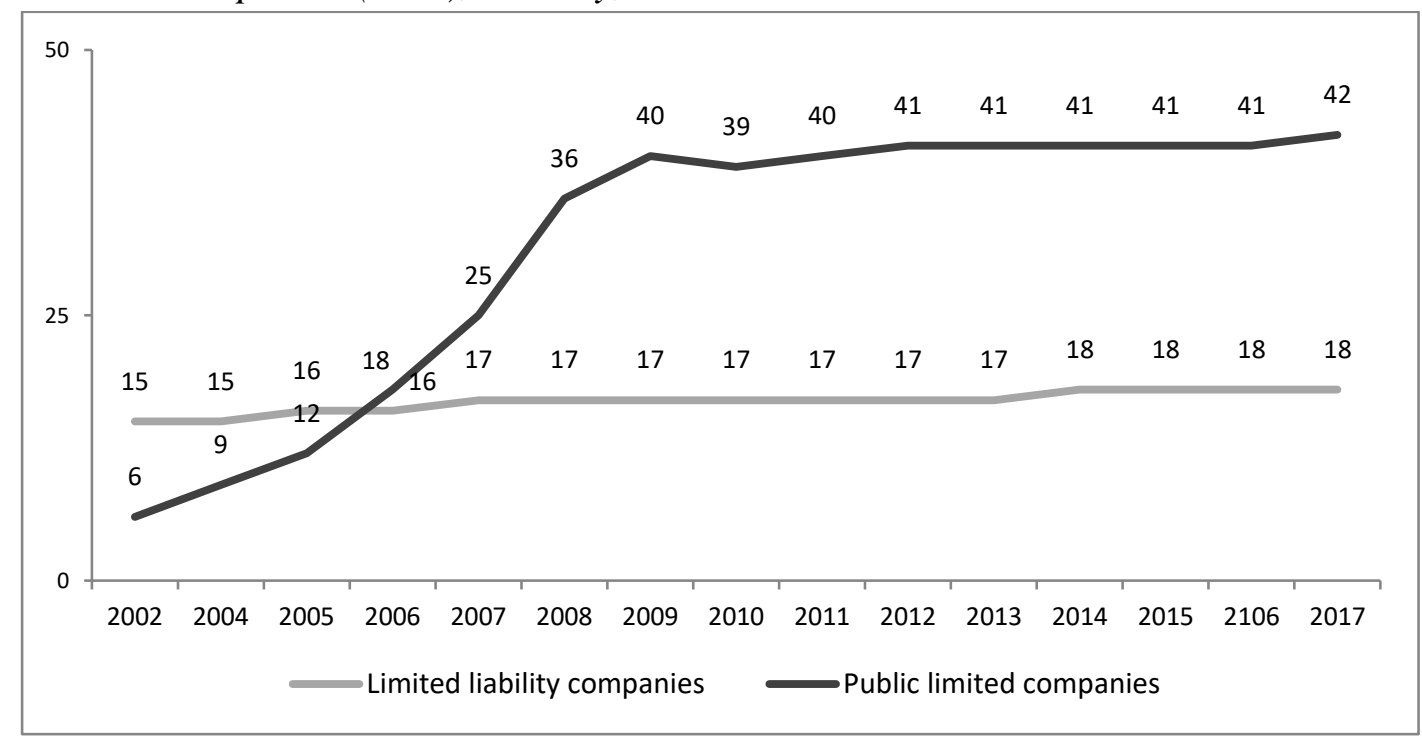

Source: Statistics Norway.

The black line (Figure 1) shows the change in the proportion of women on the boards of PLCs, and the grey line illustrates the proportion of women on the boards of LTDs, which are not subject to CBQs. The representation of women on PLC boards increased quickly after the "threat" legislation (2003-2005) became actual legislation (2005), continuing to rise until full 
implementation (2008). However, the figures indicate that the quota legislation have had no ripple effects on the company boards of LTDs.

The CBQs debate has mainly revolved around PLCs, as state interference in the board composition of companies where ownership is traded on the market, is generally understood to violate the autonomy of the business sector (Teigen 2015). Prior to the introduction of corporate quotas, the debate in Norway focused on ownership rights, shareholders democracy, equal treatment, and whether there would be enough qualified women around (Teigen 2012a). In addition, corporate quotas as demeaning to women appeared in the debate, but it was not central. Rather it was argued that women would not become full board members, but excluded from the "inner circle" of the board (Storvik and Gulbrandsen 2016). The Norwegian context therefore offers the possibility to study framing effects in a setting where the implementation of CBQs were highly controversial, but achieved its main and direct objective of gender balance quite rapidly.

\section{Data and design}

The experiment is embedded in a comprehensive survey of Norwegian elites: the 2015 Leadership Study (see Torsteinsen 2017). The elite survey sample was constructed using the so-called "position" method (Hoffmann-Lange 2007). The 1939 individuals who occupied the most important leadership positions in Norwegian society were included in the initial sample. Ten distinct societal sectors were chosen: research/education, the church, culture, the media, business, organizations, police and judiciary, politics, the state administration, and the military. The fieldwork was carried out by Statistics Norway. The interviews were conducted by telephone and personal interviews, with a response rate of 72 percent, leaving us with 1351 elite respondents. 


\section{Design, treatment, and dependent variables}

The research design followed a classic experimental approach, in which one experimental group received the treatment while the control group did not. The treatment was formulated based on the framing framework, emphasizing both the definition of the problem (male dominance in business) and a solution (CBQs). The treatment group was therefore exposed to an introductory text with information about continuous male dominance in the business sector and the success of the quota scheme in resulting in 40 percent of women on the corporate boards of listed companies:

Norwegian business life is highly male dominated. Today, there are almost no women among the corporate leaders of the largest companies, but as a result of gender quotas, there are 40 percent women on the boards of listed companies.

This treatment represents a genuine one-sided frame, as the "necessity" and success of the quota scheme was highlighted.

We investigated the effect of the treatment on two dependent variables. First, we investigated general support for CBQs. More specifically, the first dependent variable was formulated as follows:

There are several schemes that aim to equalize gender differences regarding participation in various areas of society:

Are you for or against that gender balance on the boards of listed companies should be at least 40 percent of the underrepresented gender?

The answer categories were a simple dichotomy: for or against.

We then went a step further and investigated whether the treatment would affect opinions about whether CBQs were necessary in achieving gender balance among the business elite more generally. Our second dependent variable was formulated as: 
There are differing views on whether gender quotas on corporate boards are necessary to promote gender balance in Norwegian business life. Using the scale on the card, where 0 means that gender quotas are necessary and 10 means that gender quotas are unnecessary, where would you place yourself?

In the analysis we recoded the scale so that high value (10) indicates 'necessary'.

The total elite sample was divided into a treatment group and a control group. The two samples were of the same size. Table 1 presents the distribution of the treatment group and the control group along essential factors that might influence opinions toward CBQs (gender, age, and sector). There are only minor differences relating to gender and age. In terms of sector, the church was underrepresented in the control group; however, the differences were minor.

Table 1. Descriptive Statistics of the Treatment and Control Groups

\begin{tabular}{lcc}
\hline & Treatment group & Control group \\
\hline Men & 73 & 70 \\
Women & 27 & 30 \\
\hline Age & & \\
$25-49$ & 28 & 28 \\
$50-59$ & 43 & 44 \\
$60-79$ & 28 & 28 \\
\hline Sector & & \\
Church & 10 & 7 \\
State administration & 13 & 14 \\
Culture & 8 & 9 \\
Media & 6 & 7 \\
Business & 17 & 19 \\
Organizations & 12 & 12 \\
Research/education & 12 & 10 \\
Police and judiciary & 5 & 7 \\
Military & 5 & 5 \\
Politics & 11 & 10 \\
\hline N & 674 & 677 \\
\hline
\end{tabular}




\section{Results}

First, to get an impression of elites' overall opinions regarding CBQs, we present the distribution of the two dependent variables for the total sample, both overall and by gender and elite group (Table 2). A majority of 73 percent were in favor of CBQs: the gender balance on the boards of listed companies should be at least 40 percent. The overall mean for gender quotas being necessary to promote gender balance in business life was clearly on the necessary side of the scale at 6.12 (i.e., $0-10,5$ being the center). However, there were clear differences for both questions based on gender and sector.

Table 2. Distributions of the Two Dependent Variables for the Total Sample

\begin{tabular}{l|c|cc|c}
\hline & Proportion & \multicolumn{2}{|c|}{ Quotas neccessary } & N \\
& supporting quotas** & Mean* & St.dev & \\
\hline All & 73 & 6.12 & $(2.92)$ & 1331 \\
\hline Men & 67 & 5.60 & $(2.89)$ & 956 \\
Women & 90 & 7.45 & $(2.57)$ & 375 \\
\hline Sector & 85 & & & \\
Church & 86 & 6.60 & $(2.31)$ & 113 \\
State administration & 82 & 6.62 & $(2.51)$ & 185 \\
Culture & 80 & 7.35 & $(2.41)$ & 115 \\
Media & 57 & 6.82 & $(2.55)$ & 85 \\
Business & 75 & 6.84 & $(2.99)$ & 241 \\
Organizations & 87 & 7.11 & $(2.71)$ & 150 \\
Research/education & 60 & 5.00 & $(2.94)$ & 80 \\
Police and judiciary & 53 & 5.15 & $(2.83)$ & 70 \\
Military & 68 & 5.73 & $(3.49)$ & 140 \\
Politics & 40 percent & & \\
\hline
\end{tabular}

** Proportion in support of at least 40 percent of each gender on the boards of listed companies. * Mean on a scale from 0 (not necessary) to 10 (necessary).

Nine out of ten women among the Norwegian elite supported CBQs. Although the number was lower for men, a clear majority of 67 percent supported CBQs. The gender difference was also large in terms of whether CBQs were seen as necessary to achieve gender equality, but the mean even for men leaned toward "necessary". Business elites, together with the 
police and judiciary, and the military elites, were less supportive of corporate quotas than other elites.

The question, then, is the extent to which the treatment presented above influenced elite opinions on these matters. We investigated the two dependent variables separately. First, we studied the effect of the treatment on the general support for CBQs on the boards of listed companies.

\section{General support for CBQs}

To study the effect of the treatment, we used linear probability models. ${ }^{10}$ In the model, the constant can be interpreted as the proportion supporting CBQs in the control group, and the b-coefficient indicates the difference between the control and treatment groups.

Table 3. Linear Probability Model of the Effect of the Treatment on Support for CBQs

\begin{tabular}{l|ccc}
\hline & \multicolumn{3}{|c}{ All respondents } \\
\hline Constant & $\mathrm{B}$ & $\mathrm{Se}$ & $\mathrm{p}$ \\
\hline Treatment & .70 & .02 & .00 \\
\hline $\mathrm{R}^{2}$ & $.06 * * *$ & .02 & .01 \\
\hline $\mathrm{N}: 1330$ & .004 & & \\
\hline
\end{tabular}

Dependent variable: 1 = "Support present quota scheme"; $0=$ "against the current quota scheme" $* * * \mathrm{p}<0.01 ; * * \mathrm{p}<0.05 . * \mathrm{p}<0.10$

The results presented in Table 3 clearly support the expectation that positive framing of CBQs affect support for CBQs (Hypothesis 1). The treatment group was significantly more likely to support CBQs. The effect of the treatment was $6 \mathrm{pp}$, which is clearly significant $(\mathrm{p}<$ 0.01), and indicates that 20 percent (6/30) of the elites opposing CBQs were affected.

Above, we discussed that it is possible to make the case that both elite women and men would be influenced by the treatment. Perhaps a little bit surprisingly, however, the effect of the treatment was only found among men. Table 4 shows that the men in the treatment group had a significantly higher chance of supporting the quota scheme. Only 6 of 10 men in the control group supported CBQs. However, when presented with the positive 
information, 24 percent (9/39) were affected, and in the treatment group, 7 of 10 supported CBQs. This is quite a substantial effect, and it is clearly significant. Thus, Hypothesis 3 was supported. As shown in Table 2, women were much more likely to support CBQs than men. Ninety percent of women in both the control and treatment groups supported CBQs. Thus, few women were left to persuade.

Table 4. Linear Probability Model of the Effect of the Treatment on Support for CBQs (by gender)

\begin{tabular}{l|ccc|ccc} 
& \multicolumn{3}{|c|}{ Men } & \multicolumn{3}{|c}{ Women } \\
& $\mathrm{B}$ & $\mathrm{Se}$ & $\mathrm{p}$ & $\mathrm{B}$ & $\mathrm{Se}$ & $\mathrm{p}$ \\
\hline Constant & .62 & .02 & .00 & .89 & .01 & .00 \\
Treatment & $.09 * *$ & .03 & .00 & .00 & .03 & .89 \\
\hline $\mathrm{R}^{2}$ & .01 & & & -.00 &
\end{tabular}

Dependent variable: 1 = Support present quota scheme

$* * * \mathrm{p}<0.01 ; * * \mathrm{p}<0.05 . * \mathrm{p}<0.10$

$\mathrm{N}$ : men: 955; women: 374

In Table 5, we examined the effect of the treatment among different elite groups. We expected the business elite to be particularly resistant to the treatment due to proximity and knowledge about the issue at hand (Hypothesis 4). However, we found the opposite result. Effects were generally stronger among the business elite than among other elite groups. Here, the difference between the control group and treatment group was $13 \mathrm{pp}$ (b-coefficient), which is a substantially large effect. Thus, once again, the results are the opposite of what we expected from resistance due to proximity to the policy area. Moreover, when we ran the model for men only, the effects were even stronger. The difference between the control group and the treatment group was $15 \mathrm{pp}$ (b-coefficient). ${ }^{11}$ 
Table 5. Linear Probability Model of the Effect of the Treatment on Support for CBQs by sector (The models were run for the total sample and for men only

\begin{tabular}{|c|c|c|c|c|c|c|c|}
\hline & & \multicolumn{3}{|c|}{ Total sample } & \multicolumn{3}{|c|}{ Men } \\
\hline & & B & $\begin{array}{c}\text { Std. } \\
\text { Error }\end{array}$ & p-values & B & $\begin{array}{l}\text { Std. } \\
\text { Error }\end{array}$ & p-values \\
\hline \multirow[t]{2}{*}{ Church } & & .82 & .05 & .00 & .81 & .07 & .00 \\
\hline & Treatment & .04 & .07 & .58 & .00 & .09 & 1.00 \\
\hline \multirow[t]{2}{*}{ State administration } & Constant & .82 & .04 & .00 & .72 & .05 & .00 \\
\hline & Treatment & .07 & .05 & .17 & $.16^{* *}$ & .07 & .04 \\
\hline \multirow[t]{2}{*}{ Culture } & Constant & .80 & .05 & .00 & .79 & .06 & .00 \\
\hline & Treatment & .03 & .07 & .68 & .02 & .10 & .83 \\
\hline \multirow[t]{2}{*}{ Media } & Constant & .80 & .06 & .00 & .71 & .08 & .00 \\
\hline & Treatment & -.01 & .09 & .91 & .06 & .12 & .61 \\
\hline \multirow[t]{2}{*}{ Business } & Constant & .50 & .04 & .00 & .45 & .05 & .00 \\
\hline & Treatment & $.13^{* *}$ & .06 & .04 & $.15^{* *}$ & .07 & .04 \\
\hline \multirow[t]{2}{*}{ Organizations } & Constant & .77 & .05 & .00 & .69 & .06 & .00 \\
\hline & Treatment & -.05 & .07 & .45 & -.01 & .08 & .88 \\
\hline \multirow[t]{2}{*}{ Research/education } & Constant & .82 & .04 & .00 & .74 & .06 & .00 \\
\hline & Treatment & .08 & .06 & .16 & .13 & .08 & .14 \\
\hline \multirow[t]{2}{*}{ Police and judiciary } & Constant & .56 & .07 & .00 & .48 & .09 & .00 \\
\hline & Treatment & .09 & .11 & .42 & .12 & .13 & .37 \\
\hline \multirow[t]{2}{*}{ Military } & Constant & .53 & .09 & .00 & .53 & .09 & .00 \\
\hline & Treatment & .00 & .12 & .99 & .02 & .12 & .90 \\
\hline \multirow[t]{2}{*}{ Politics } & Constant & .65 & .06 & .00 & .55 & .08 & .00 \\
\hline & Treatment & .07 & .08 & .41 & .10 & .11 & .37 \\
\hline
\end{tabular}

Dependent variable: $1=$ Support present quota scheme

$* * * p<0.01 ; * * p<0.05 . * \mathrm{p}<0.10$

\section{Effect of CBQs as necessary to promote gender balance in business life}

In this section, we analyze the effect on the second dependent variable: opinions on the extent to which CBQs are necessary to promote gender balance in business life in general. Our main hypothesis was that when exposed to positive framing, elites would become more supportive of this statement (Hypothesis 1b). 
Table 6. OLS Regression of the Effect of the Treatment on CBQs as Necessary to Promote Gender Balance

\begin{tabular}{l|ccc}
\hline & \multicolumn{3}{|c}{ All respondents } \\
\hline Constant & $\mathrm{B}$ & $\mathrm{Se}$ & $\mathrm{p}$ \\
\hline Treatment & 6.09 & $(.12)$ & .00 \\
\hline $\mathrm{R}^{2}$ & .05 & $(.16)$ & .73 \\
\hline $\mathrm{N}: 1347$ & .00 & & \\
\hline
\end{tabular}

$\mathrm{N}: 1347$

Dependent variable: $0-10$

$* * * \mathrm{p}<0.01 ; * * \mathrm{p}<0.05 . * \mathrm{p}<0.10$

Table 6 reports on the overall effect of the treatment and does not support the expectation that the treatment will increase adherence to the belief that CBQs are necessary to promote gender balance in the business sector. There was no significant difference between the treatment and control groups. Thus, Hypothesis $1 \mathrm{~b}$ was not supported. The intercept indicates the mean for the control group. The difference between the control group and the treatment group only constitutes five percent of one scale point on the scale from 0-10 and should be considered negligible. For Table 7, we ran the model separately for men and women.

Table 7. OLS Regression of the Effect of the Treatment on CBQs as Necessary to Promote Gender Balance (by gender)

\begin{tabular}{l|ccc|rrr}
\hline & \multicolumn{3}{|c|}{ Men } & \multicolumn{3}{|c}{ Women } \\
& $\mathrm{B}$ & $\mathrm{se}$ & $\mathrm{P}$ & $\mathrm{B}$ & $\mathrm{Se}$ & $\mathrm{p}$ \\
\hline Constant & 5.54 & .13 & .00 & 7.41 & .18 & .00 \\
Treatment & .12 & .19 & .54 & .09 & .27 & .73 \\
\hline $\mathrm{R}^{2}$ & .00 & & & -.00 & & \\
\hline
\end{tabular}

$\mathrm{N}$ : men, 955; women, 374

Dependent variable: $0-10$

$* * * \mathrm{p}<0.01 ; * * \mathrm{p}<0.05 . * \mathrm{p}<0.10$

As illustrated in Table 2, women were much more inclined than men to believe that CBQs are necessary to promote gender balance in business life in general. However, this difference was not due to women being more influenced by the treatment than men. Again, there were no significant differences between the treatment and control groups, and neither Hypothesis 2 nor 3 was supported in this case. 
Table 8. OLS Regression of the Effect of the Treatment on CBQs as Necessary to Promote Gender Balance (by elite sector)

\begin{tabular}{|c|c|c|c|c|c|c|c|}
\hline & & \multicolumn{3}{|c|}{ Total } & \multicolumn{3}{|c|}{ Men } \\
\hline & & $\mathrm{b}$ & $\begin{array}{r}\text { Std. } \\
\text { Error }\end{array}$ & $\mathrm{p}$ & $\mathrm{b}$ & $\begin{array}{r}\text { Std. } \\
\text { Error }\end{array}$ & $\mathrm{p}$ \\
\hline \multirow[t]{2}{*}{ Church } & Constant & 6.16 & .34 & .00 & 5.91 & .41 & .00 \\
\hline & Treatment & $0.74 *$ & .44 & .10 & 0.52 & .52 & .32 \\
\hline \multirow[t]{2}{*}{ State administration } & Constant & 6.81 & .26 & .00 & 6.29 & .33 & .00 \\
\hline & Treatment & -0.39 & .37 & .29 & -0.08 & .46 & .86 \\
\hline \multirow[t]{2}{*}{ Culture } & Constant & 7.33 & .31 & .00 & 7.05 & .41 & .00 \\
\hline & Treatment & 0.04 & .45 & .93 & -0.55 & .66 & .41 \\
\hline \multirow[t]{2}{*}{ Media } & Constant & 7.09 & .38 & .00 & 6.25 & .45 & .00 \\
\hline & Treatment & -0.57 & .56 & .30 & 0.11 & .62 & .87 \\
\hline \multirow[t]{2}{*}{ Business } & Constant & 4.55 & .26 & .00 & 4.15 & .28 & .00 \\
\hline & Treatment & $0.63 *$ & .38 & .10 & $0.77 *$ & .40 & .06 \\
\hline \multirow[t]{2}{*}{ Organizations } & Constant & 6.29 & .31 & .00 & 5.93 & .38 & .00 \\
\hline & Treatment & -0.03 & .44 & .94 & -0.01 & .53 & .98 \\
\hline \multirow[t]{2}{*}{ Research/education } & Constant & 7.13 & .33 & .00 & 6.41 & .44 & .00 \\
\hline & Treatment & -0.03 & .45 & .94 & 0.30 & .59 & .62 \\
\hline \multirow[t]{2}{*}{ Police and judiciary } & Constant & 5.20 & .44 & .00 & 4.81 & .49 & .00 \\
\hline & Treatment & -0.46 & .66 & .49 & -0.48 & .69 & .49 \\
\hline \multirow[t]{2}{*}{ Military } & Constant & 5.49 & .48 & .00 & 5.49 & .47 & .00 \\
\hline & Treatment & -0.65 & .67 & .33 & -0.70 & .67 & .30 \\
\hline \multirow[t]{2}{*}{ Politics } & Constant & 5.79 & .43 & .00 & 5.15 & .53 & .00 \\
\hline & Treatment & -0.11 & .59 & .85 & -0.38 & .72 & .61 \\
\hline
\end{tabular}

Dependent variable: $0-10$

$* * * p<0.01 ; * * p<0.05 . * \mathrm{p}<0.10$

The treatment seemed, however, to affect certain elite sectors (Table 8). The expectation was that the business elite would be less affected by the treatment than other elite groups due to their proximity to the issue at hand. Contrary to expectations, the effects were generally stronger among the business elite than in other elite groups. The difference between the treatment and control groups was quite large and significant at the 10 percent level for the business elite. As shown (Table 2), at the outset, the business elite were the most negative toward the notion that CBQs are necessary to promote gender balance among their rank. The 
difference between the control and treatment groups was 0.6 , indicating that the business elite in the control group were highly negative; however, the treatment enabled the business elite to move toward other elites. Again, the effects were even stronger when only men were included in the analysis. However, the mean derived from business elites who were exposed to the treatment (5.18) was still lower than the mean in all other elite groups.

\section{Discussion and conclusion}

Gender quotas and corporate quotas in particular, have been met with severe opposition. In this article we have shown that such opposing opinions can be influenced by a positive frame. Elites have been thought to be more resistant to framing, as their predispositions have been found to be stronger and more consistent than those of the general public (e.g., Zaller 1992). However, few if any studies have empirically investigated framing effects on national elites. In this article, we investigated whether national elites, the people occupying the top echelons across ten sectors in Norwegian society, are susceptible to positive framing of CBQs. The results clearly indicate that indeed they are. When exposed to information about prevailing male dominance among the business elite and the success of CBQs in achieving gender balance on corporate boards, the elites were significantly more likely to support gender quotas. The effect was quite substantial: One in five was influenced by the treatment. The effect was primarily found among men, the 10 percent of women who opposed CBQs were not easily persuaded. Interestingly, and contrary to expectations, the effect was strongest for men in the business elite. ${ }^{12}$

Framing had a more modest effect on the second dependent variable: if CBQs are necessary to promote gender balance in business life in general. Overall, there was no difference between the control and treatment groups. The treatment did not contain any information about such ripple effects, and indeed, empirical studies indicate that such effects 
are hard to find (see Halrynjo et al. 2015; Bertrand et al. 2017), ${ }^{13}$ so it is no surprise that effects of the treatment are weaker on this variable. However, again, men in the business elite were influenced.

Opposition to corporate quotas has been most strongly expressed by business actors (Skjeie and Teigen 2003; Chandler 2016). As such, the finding that the effects were generally stronger among the business elite was surprising, and the contrary of what we expected. As the CBQs jurisdiction concerns their sector, we expected the issue to be most salient for the business elite compared to other elites and that they would have more in-depth knowledge about the issue - resulting in strong predispositions. In what follows, we formulate three arguments to help explain this result.

First, our study indicates that it is not always the case that the one wearing the shoes knows best where it is pushing. Although challenges relating to gender equality are particularly pronounced in the business sector, it might not necessarily mean that the awareness of the situation within business is particularly high or that the salience of the issue is exceedingly high. The relatively low level of support for CBQs among the business elite does suggest that other frames that are perhaps more typical in a business setting, such as non-state intervention and ownership rights, are the more easily accessible frames for this group. The results nevertheless suggest that these general frames can take the backseat to gender equality frames when presented with specific information about the issue. However, the only restriction CBQs lays on ownership rights is that candidates have to be selected from the whole population, not exclusively the one half consisting only of men. Hence, CBQs are not necessarily at odds with owners' autonomy, and it could be possible to integrate support for corporate quotas with these types of considerations. ${ }^{14}$

Second, and highly related to the first point, although opposition to CBQs was voiced by business elites in the media, the dominant elite frames documented in much earlier 
research, were not generated by an entire group of elites, but more likely by a subgroup of especially engaged people, key stakeholders acting as (elite) opinion leaders on this subject. Thus, while these particularly engaged segments of the elite will be resistant to framing, as they most likely have strong predispositions on the issue, other less engaged segments might be less resistant. Moreover, while studies of elites and social class has started to examine political attitudes in their research agenda (e.g., Flemmen 2014), little is still known about differences in the individual ideological consistency between elite groups. One possibility is that business elites have less ideologically coherent attitudes than other elite groups and are, therefore, more susceptible to framing. This should be an interesting avenue for future research.

Third, because the opposition to CBQs is strongest within the business sector, the potential for change is arguably also greatest in that group. Thus, a research design that also included a negative frame would therefore have been more balanced. However, while a research design with two treatment groups would have worked for the entire elite sample, it would have prevented the testing of differences between elite groups, as the $\mathrm{N}$ would have been too small. Hence, a balanced design would have come at the expense of the study of effects within the business elite.

In the literature and public debates, opinions on gender quotas are linked to larger ideologically fronts concerning individual rights, equal treatment, fairness, and justice. In this perspective, opinions can give the impression of fixed or frozen cleavages. However, the results in this article show that attitudes toward CBQs are influenced by the framing of the issue and that opinions are easier to defrost than perhaps often believed. Even though this experiment, like all experiments, have problems with external validity, like the enduring effect of framing (e.g. Lecheler and de Vreese 2011), the results suggest that the frames that dominate a public debate can sway elite opinions. 
We have investigated opinions towards corporate quotas in one type of context: a country with continuous male dominance in business life, but with successfully implemented corporate quotas. The results from this context are important for the body of work on gender and politics for at least two reasons: Continuous support for an implemented policy is essential to prevent backlash and dismantling of policies. Elite opinion change about CBQs due to positive framing is therefore essential knowledge. Moreover, that it is possible to change opinions even in the Norwegian context where CBQs were highly debated prior to implementation, suggest that is possible to do so also in other types of contexts. However, to increase our knowledge about elite opinion change on gender-equality policy issues, studies that investigate attitude change to quota policies that is not yet in place would be most welcome. So would studies investigating CBQs opinion change in contexts where CBQs are not adopted. Such studies would offer clues about the scope conditions for influencing elite opinions on gender policy issues.

The results in this article have potentially serious implications for the formulation of public policy. They support results from studies on the international diffusion of political quotas that indicate that the way in which gender issues are framed and the particular political constellations at the time have a strong impact on whether gender quotas are adopted or not (Krook 2009, 218-222). These earlier studies did not, however, investigate whether elites themselves are influenced by how the issue is framed. Our study indicates that even relevant elite stakeholders are affected by the framing of issues and suggests that policymakers might consider opposition to policy issues, even among national elites, as something it is possible to influence and change. 


\section{Notes}

\footnotetext{
${ }^{1}$ See Teigen (2012a); Terjesen and Sealy (2016); Mensi-Klarbach et al. (2017); Piscopo and Muntean (2018); Lépinard and Marin (2018)

${ }^{2}$ https://www.idea.int/data-tools/data/gender-quotas/quotas

${ }^{3}$ See (www.ipu.org).

${ }^{4}$ The psychological processes behind framing effects are debated in the literature see e.g. de Vreese and Lecheler 2012 for an overview.
}

${ }^{5}$ Recently, some scholars argue for a clearer distinction between information and framing (e.g., Leeper and Slothus 2015). In this paper, we subscribe to the perspective that presenting certain types of information does constitute framing.

${ }^{6} \mathrm{PLC}$ (public limited company) is a registration form necessary for all traded companies. The shares of PLC's are owned by all types of owners (individual private owners, institutional private and public, owners, and by the Norwegian state).

${ }^{7}$ The rules are formulated as follows: 1) Where there are two or three board members, both genders should be represented. 2) Where there are four or five board members, both genders should be represented by at least two members. 3) Where there are six to eight board members, both genders should be represented by at least three members. 4) Where there are nine or more board members, the membership should comprise at least $40 \%$ men and $40 \%$ women. 5) Rules 1 to 4 also apply to the election of deputy members.

${ }^{8}$ LTDs are limited liability companies. The vast amount of these companies is small and medium sized, still among the 200 biggest companies, about two-thirds are LTDs and one-third PLCs.

${ }^{9}$ The number of PLCs diminished quite dramatically in the years after the introduction of CBQs. It has been argued that the correlation between these expresses a silent protest (Bøhren \& Staubo 2014). The argument is however contested. Heidenreich and Storvik (2010) find that very few of the companies that changed from PLC to LTD did it as a response to the CBQs.

${ }^{10}$ See Finseraas and Jakobsson (2014) for a similar approach.

${ }^{11}$ In addition, men among the state administration elite were influenced by the treatment, where the difference between the control and treatment groups was $16 \mathrm{pp}$ (b-coefficient). 
${ }^{12}$ The survey relies on telephone and personal interviews and the treatment might therefore trigger responses based on social desirability. Arguably, elites are more resistant to social desirability effects than the general public, and such effects should have been consistent across sectors.

${ }^{13}$ See also https://www.samfunnsforskning.no/core/bilder/core-topplederbarometer/coretopplederbarometer_pdf/core-norwegian-gender-balance-scorecard-2018.pdf

${ }^{14}$ Moreover, recently, the argument that more women on boards are good for business has become more prominent in the debate on CBQs (Tienari et al. 2009; Teigen 2015; Chandler 2016; Piscopo and Muntean 2018). It is possible that the positive CBQs frame presented in the treatment also made the "women are good for business" frame more salient.

\section{References}

Ajzen, Icek and Martin Fishbein. 1980. Understanding Attitudes and Predicting Social Behavior. Englewood Cliffs, NJ: Prentice-Hall.

Axelsdóttir, Laufey and Thorgerdur Einarsdóttir. 2016. “The Realization of Gender Quotas in Post-collapse Iceland.” NORA - The Nordic Journal of Women Studies 25 (1): 48-61. Bacchi, Carol. 2009. "The Issue of Intentionality in Frame Theory: The Need for Reflexive Framing." In The Discursive Politics of Gender Equality, ed. Emanuela Lombardo, Petra Meier, and Mieke Verloo. London and New York: Routledge.

Bertrand, Marianne, Sandra E. Black, Sissel Jensen, and Adriana Lleras-Muney. 2014. "Breaking the Glass Ceiling? The Effect of Board Quotas on Female Labor Market Outcomes in Norway." National Bureau of Economic Research.

Bøhren, Øyvind and Siv Staubo. 2014. "Does Mandatory Gender Balance Work? Changing organizational form to avoid board upheaval. Journal of Corporate Finance, 28, 152168. Doi: 10.1016/j.jcorpfin.2013.12.005 
Chandler, Andrea. 2016. "Women on Corporate Boards: A Comparison of Parliamentary Discourse in the United Kingdom and France." Politics \& Gender, 12. DOI: http://dx.doi.org/10.1017/S1743923X15000574

Chong, Dennis and James N. Druckman. 2007a. "Framing Theory." Annual Review of Political Science 10: 103-26.

Chong, Dennis and James N. Druckman. 2007b. "A Theory of Framing and Opinion Formation in Competitive Elite Environments.” Journal of Communication 57: 99118.

Chong, Dennis and James N. Druckman. 2013. “Counterframing Effects.” Journal of Politics 75 (1): $1-16$.

Clayton, Amanda, Diane Z. O’Brien and Jenifer M. Piscopo. 2018. “All Male Panels? Representation and Democratic Legitimacy”. American Journal of Political Science, Vol. 00, No. 0, xxxx 2018. 1-17. DOI: 10.1111/ajps.12391

Converse, Philip. 1964. “The Nature of Belief Systems in Mass Publics.” In Ideology and Discontent, edited by David E. Apter. New York: Free Press.

Dahlerup, Drude and Lenita Freidenvall. 2005. “Quotas as a 'fast track' to equal representation for women”. International Feminist Journal of Politics 7 (1), 26-48. doi:10.1080/1461674042000324673

Dahlerup, Drude. 2008. “Gender Quotas - Controversial but Trendy.” International Feminist Journal of Politics 10 (3): 322-28.

De Vreese, Claes, and Sophie Lecheler (2012) "News Framing Research: an Overview”. In The Sage Handbook of Political Communication, ed. H. A. Semetko and M. Scammel. London:Sage.

Disch, Lisa. 2011. "Toward a Mobilization Conception of Democratic Representation." American Political Science Review 105 (1): 100-14. 
Entman, Robert M. 1993. "Framing: Toward Clarification of a Fractured Paradigm.” Journal of Communication 43 (4): 51-58.

Fagan, Colette, Maria González Menéndez, and Silvia Gómez Ansón, S. 2012. Women on Corporate Boards and in Top Management: European Trends and Policy. London: Palgrave.

Finseraas, Henning and Niklas Jakobsson. 2014. "Does Information about the Pension System Affect Knowledge and Retirement Plans? Evidence from a Survey Experiment". Journal of Pension Economics and Finance 13: 250-271.

Flemmen, Magne. 2014. "The Politics of the Service Class: The Homology of Positions and Position-Takings.” European Societies 16 (4): 543-569. https://doi.org/10.1080/14616696.2013.817597

Goerres, Achim, Rune Karlsen \& Staffan Kumlin (2018) What Makes People Worry about the Welfare State? A Three-Country Experiment. British Journal of Political Science. doi:10.1017/S0007123418000224

Halrynjo, Sigtona, Mari Teigen, and Marjan Nadim. 2015. Kvinner og menn i toppledelsen. In Virkninger av kjфnnskvotering i norsk naringsliv, ed. Mari Teigen. Oslo: Gyldendal akademisk.

Heidenreich, Vibeke and Aagoth Storvik. 2010. Rekrutteringsmønstre, erfaringer og holdninger til styrearbeid blant ASA-selskapenes styrerepresentanter. Oslo: Institute for Social Research.

Hoffmann-Lange, Ursula. 2007. "Methods of Elite Research". In, The Oxford Handbook of Political Behavior, ed. R. J. Dalton \& H. D. Klingemann. DOI: 10.1093/oxfordhb/9780199270125.003.0049 
Hughes, Melanie M., Paxton Pamela, and Krook Mona Lena. 2017. "Gender Quotas for Legislatures and Corporate Boards.” Annual Review of Sociology 43: 331-52. https://doi.org/10.1146/annurev-soc-060116-053324.

Krook, Mona Lena. 2009. Quotas for Women in Politics. New York: Oxford University Press.

Lecheler, Sophie and Claes H. de Vreese (2011). Getting real: The duration of framing effects. Journal of Communication, 61(5), 959-983. doi: 10.1111/j.14602466.2011.01580.x

Leeper, Thomas J. and Rune Slothus. 2015. "Can Citizens Be Framed? How Information More than Emphasis Changes Opinions". Paper presented at the 1st GothenburgBarcelona workshop on experimental political science Gothenburg, Sweden, May, 7.8.

Lépinard, Eléonore and Ruth Rubio Marin. 2018. Transforming Gender Citizenship: The Irresistible Rise of Gender Quotas in Europe. Cambridge: Cambridge University Press.

Lépinard, Eléonore. 2018. “The French Parity Reform: The Never-Ending Quest for A New Gender Equality Principle. In Transforming Gender Citizenship: The Irresistible Rise of Gender Quotas in Europe, ed. Eléonore Lépinard and Ruth Rubio Marin. Cambridge: Cambridge University Press.

Lombardo, Emanuela, Petra Meier, and Mieke Verloo. 2009. The Discursive Politics of Gender Equality. London and New York: Routledge.

Menéndez González, Maria C., and Lara Martínez González. 2012. "Spain on the Norwegian Pathway: Towards a Gender-Balanced Presence of Women on Corporate Boards.” In Women on Corporate Boards and in Top Management: European Trends and Policy, 
ed. Colette Fagan, Maria González Menéndez, and Silvia Gómez Ansón, S. London: Palgrave.

Mensi-Klarback, Cathrine Seierstad, and Patricia Gabaldon. 2017. "Setting the Scene:

Women on Boards: The Multiple Approaches beyond Quotas.” In Gender Diversity in the Boardroom: Multiple Approaches Beyond Quotas, Volume 2, ed. Cathrine Seierstad, Patricia Gabaldon and Heike Mensi-Klarbach. London: Palgrave Macmillan.

Murray, Rainbow. 2014. “Quotas for Men: Reframing Gender Quotas as a Means of Improving Representation For All”. American Political Science Review, Vol. 108, 3, 520-532. https://doi.org/10.1017/S0003055414000239

Iyengar, Shanto. 1991. Is Anyone Responsible? How Television Frames Political Issues. Chicago: University of Chicago Press.

Piscopo, Jennifer M. and Susan Clark Muntean 2018. "Corporate Quotas and Symbolic Politics in advanced Democracies”. Journal of Women, Politics and Policy, 39(3): 285-389. DOI: 10.1080/1554477X.2018.1477396

Scheufele, Dietram A. and Shanto Iyengar. 2017. "The state of Framing Research: A Call for New Directions." In The Oxford Handbook of Political Communication, ed. Kate Kenski and Kathleen H. Jamieson. New York: Oxford University Press.

Seierstad, Cathrine, Patricia Gabaldon and Heike Mensi-Klarbach. 2017. Gender Diversity in the Boardroom: Multiple Approaches Beyond Quotas, Volume 2, London: Palgrave Macmillan.

Skjeie, Hege and Mari Teigen. 2003. Menn imellom. Oslo: Gyldendal akademisk.

Slothuus, Rune 2007. "Framing deservingness to win support for welfare state retrenchment." Scandinavian Political Studies 30(3): 323-344. 
Storvik, Aagoth and Trygve Gulbrandsen. 2016. "Included, but still not equal? Gender segregation at quota regulated boards." Corporate Board: role, duties and composition, 12 (2): 35-45. http://doi.org/10.22495/cbv12i2art5

Teigen, Mari. 2000. “The Affirmative Action Controversy.” NORA - The Nordic Journal of Women Studies 8 (2): 63-77.

Teigen, Mari. 2012a. “Gender Quotas for Corporate Boards in Norway - Innovative Gender Equality Policy." In Women on Corporate Boards and in Top Management: European Trends and Policy, ed. Colette Fagan, Maria González Menéndez, and Silvia Gómez Ansón, S. London: Palgrave.

Teigen, Mari 2012b. "Gender Quotas in Corporate Boards - On the diffusion of a distinct national policy reform". In, Firms, Boards and Gender Quotas: Comparative Perspectives, ed. Fredrik Engelstad and Mari Teigen. Comparative Social Research, 29. Bingley: Emerald (2012), 115-146.

Teigen, Mari. 2015. “The Making of Gender Quotas for Corporate Boards in Norway”. In Cooperation and Conflict the Nordic Way. Work, Welfare and Institutional Change in Scandinavia, ed. Anniken Hagelund and Fredrik Engelstad. De Gruyter Open. https://doi.org/10.1515/9783110436891

Teigen, Mari. 2018a. "The "natural” prolongation of the Norwegian Gender Equality Policy Institution”. In, Transforming Gender Citizenship: The irresistible rise of gender quotas in Europe, ed. Lépinard, Eléonore and Ruth Rubio Marin Cambridge: Cambridge University Press. Chapter 11, 341-365

Teigen, Mari 2018b. "Can descriptive representation be justified outside politics?” In Democratic State and Democratic Society, ed. Engelstad, Fredrik, Cathrine Holst and Gunnar C. Aakvaag. De Gruyter Open (forthc.). 
Terjesen, Siri and Ruth Sealy. 2016. "Board Gender Quotas: Exploring Ethical Tensions from a Multi-Theoretical Perspective.” Business Ethics Quarterly 26 (1): 23-65. DOI: 10.1017/beq.2016.7.

Terjesen, Siri, Ruth Aguilera, and Ruth Lorenz. 2015. 'Legislating a Woman's Seat on the Board: Institutional Factors Driving Gender Quotas for Boards of Directors.” Journal of Business Ethics 128 (2): 233-251. DOI 10.1007/s10551-014-2083-1.

Tienari, Janne, Charlotte Holgersson, Susi Meriläinen and Pia Höök. 2009. “Gender, Management and Market Discourse: The Case of Gender Quotas in Swedish and Finnish Media." Gender, Work \& Organization 16 (4): 501-f521.

Torsteinsen, Arnhild. 2017. Lederskapsundersøkelsen 2015. Oslo: Statistics Norway. Tversky, Almos and Daniel Kahneman. 1981. "The Framing of Decisions and the Psychology of Choice.” Science 211: 453-458.

Verloo, Mieke. 2005. "Displacement and Empowerment: Reflection on the Concept and the Practice of the Council of Europe Approach to Gender Mainstreaming and Gender Equality.” Social Politics 12 (3): 344-365. https://doi.org/10.1093/sp/jxi019.

Walgrave, Stefaan, Julie Sevenans, Kirsten van Camp and Peter Loewen (2018) What Draws Politicians’ Attention? An Experimental Study of Issue Framing and its Effect on Individual Political Elites. Political Behavior 40:547-569.

Zaller, John. 1992. The Nature and Origins of Mass Opinion. New York: Cambridge University Press.

\section{Appendix}

Table A1. Original and English Translation of the Treatment Text

\begin{tabular}{l|l}
\hline Original & English translation \\
\hline Norsk næringsliv er svært mannsdominert. I & Norwegian business life is highly male \\
dag er det nesten ingen kvinner blant & dominated. Today, there are almost no \\
konsernlederne for de største selskapene. & women among the corporate leaders of the \\
\hline
\end{tabular}




\begin{tabular}{l|l}
\hline $\begin{array}{l}\text { Men som en følge av kvotering er det } 40 \\
\text { prosent kvinner i styrene for de børsnoterte } \\
\text { selskapene. }\end{array}$ & $\begin{array}{l}\text { largest companies. But as a result of gender } \\
\text { quotas, there are } 40 \text { percent women on the } \\
\text { boards of listed companies. }\end{array}$ \\
\hline
\end{tabular}

Table A2. Original and the English Translation of the Dependent Variables

\begin{tabular}{|c|c|}
\hline Original & English translation \\
\hline $\begin{array}{l}\text { Er du for eller i mot at... kjønnsfordelingen } \\
\text { i styrene for børsnoterte selskap skal være på } \\
\text { minimum } 40 \text { prosent av det } \\
\text { underrepresenterte kjønn? }\end{array}$ & $\begin{array}{l}\text { Are you for or against that... gender balance } \\
\text { on the boards of listed companies should be } \\
\text { at least } 40 \text { percent of the underrepresented } \\
\text { gender? }\end{array}$ \\
\hline $\begin{array}{l}\text { Det er ulike syn på om kjønnskvotering i } \\
\text { bedriftenes styrer er nødvendig for å } \\
\text { fremme kjønnsbalanse i norsk næringsliv. } \\
\text { Hvis du bruker skalaen på kortet, der } 0 \text { betyr } \\
\text { at kjønnskvotering er nødvendig og } 10 \text { betyr } \\
\text { at kjønnskvotering er unødvendig, hvor vil } \\
\text { du plassere deg selv? }\end{array}$ & $\begin{array}{l}\text { There are differing views on whether gender } \\
\text { quotas on corporate boards are necessary to } \\
\text { promote gender balance in Norwegian } \\
\text { business life. Using the scale on the card, } \\
\text { where } 0 \text { means that gender quotas are } \\
\text { necessary and } 10 \text { means that gender quotas } \\
\text { are unnecessary, where would you place } \\
\text { yourself?* }\end{array}$ \\
\hline
\end{tabular}

*We recoded the scales so that necessary is high value (10). 